\title{
Key Factors Contributing to the Development of the Global Mindset of Managers Using PLS-SEM
}

\author{
Alexander Wollenberg, Juan José Cabrera Lazarini, and Mohammed Reinaldo Rizal
}

\begin{abstract}
The globalization in the contemporary business world has forced managers to adopt global mindsets to stay competitive in global market conditions. Several authors have argued that International experience could act as a driver to unlock the potential of a managerial global mindset orientation. However, prior research mostly focused on the capital perspective while literature surrounding international experience broken down into its components is still inadequate. Therefore, our research attempts to bridge the gap regarding the role of international experience and its components of international education, international assignments, and international training. This research utilizes exploratory factor analysis as the selected methodology and utilizes Partial Least Squares software as the research tool to analyze the data. We found that all construct variables within international experience were highly significant. Moreover, our research concludes that international training and education have a higher contribution towards the development of managers' global mindsets compared to international education. We researched managers of subsidiaries of European, US, and Australian MNCs in Singapore and Mexico City. In addition to providing a theoretical contribution, our research also contributes relevant findings surrounding the context of global mindset and managerial practices as practical implications.
\end{abstract}

Index Terms - International assignment, international education, global mindset, strategy, PLS-SEM.

\section{INTRODUCTION}

In the current interconnected business setting, it is important for an organization to increase their presence and participate in international business. However, to succeed and withstand in global markets, organizations require highly competent managers that possess global mindsets [1], [2]. As such, the mindset and characters will empower managers to inspire, manage, and govern others despite diverse cultural backgrounds, political views, institutional backgrounds, and other contextual factors that affect their actions, communication styles, and thinking [3]. Previous research emphasizes the capital element that contributes to the development of global mindsets, specifically social capital, intellectual capital, and physiological capital [4], [5]. However, several studies show that there is diminutive research that examines the relationship between international experience and the development of global mindset [6], [7]. Moreover, there is still a lack of

Manuscript received October 23, 2019; revised January 17, 2020.

Alexander Wollenberg is with Khalifa University, UAE (e-mail: awollenb@yahoo.com).

Juan José Cabrera Lazarini is with the Tecnológico de Monterrey, Mexico.

Mohammed Reinaldo Rizal is with Curtin Uniersity, Singapore Campus, Singapore. justification between the context of international assignments and global mindset formation [8], [9]. Hence, this paper endeavors to bridge and examine the highlighted gap in the previous literature review.

\section{LITERATURE REVIEW}

\section{A. Global Mindset}

According to [10], global mindset is a behavior rather than a set of skills. Global mindset is an orientation to the world that allows manager to foresee, predict, and notice certain things that others do not [10]. Managers that possess global mindsets are able to shape the world comprehensively, find opportunities and identify threats to accomplish personal goals or organizational objectives [11], [12]. Similarly, [13] asserted that individuals that attain a global mindset cognitively equalize the main three concerns consisting of competing countries, business, and functional concerns. Moreover, a global mindset provides managers with the vision and awareness to distinguish organizational interdependence in the global economy despite the fact that organizational activities tend to be limited to the domestic market [14], [15]. Other researchers argue that global mindset is not limited to the interdependence concept. As such, a global mindset is the "ability of individuals to develop and interpret criteria for personal or business performance that are independent from one solely perspective in terms of culture and context and to implement those criteria adequately in another culture and context [16]. In addition, [1] conceptualize global mindset as a knowledge structure described by both high diversity and high incorporation.

\section{B. International Experience and Global Mindset}

International experience has been shown to be one of the sources of competitive advantage in the global marketplace and contributed to the development of a global mindset [17][21]. Numerous firms' human resources recruiters have pointed to the importance of international experience and prior research has proven its positive relationship on firm performance [8], [22], [23]. International experience is considered a positive advantage at most management levels since it augments an individual's interpersonal skills and flexibility in managing problems and company dilemmas [24]-[26]. Researchers suggest several international experience mechanisms can be used to develop a global mindset such as education, cross-border or international projects, international meetings, international training locations, and expatriation or international assignments [1], [27]. Particular researchers also suggest that international 
experience represented by an international assignment [28][30] and international education should be considered as the facilitator to cultivate a managers' global mindset orientation [31], [32].

\section{International Assignment and Global Mindset}

[33] define an international assignment as working and staying overseas for at least six months to one year. Various researchers have suggested that international assignments could be one of the supporting factors in developing leaders with global mindsets [29], [30], [34]. The overseas assignment provides managers with living in different environment and thus allowing them to cultivate connections and affiliations among worldwide operations [30], [35], [36]. International assignments also expose the manager to a different value system, language, economic and socio-political environment and therefore implant sociocultural intelligence that contributes towards the development of a global mindset [15], [37]-[40]. Moreover, past findings from [41] and [42] found that there is a significant difference in the level of competencies of successful global executives for those who experience overseas settings. These researchers explained several distinctive competencies such as focus on goals, managing, clarity of communication, and openness of attitude, which is important for global mindset orientations. Hence, international assignments are expected to increase a manager's capabilities in examining and organizing firm capabilities and assisting the organization in adapting to the dynamics of a global business environment [8], [9], [43][45].

\section{International Education and Global Mindset}

Besides international assignments, research has also shown that international education can contribute to the development of global leaders [46]. It has been shown that managers with an international education would have a higher degree of international market information [46]. Previously, [47] found that managers with international education have a higher level of international experience compared to overseas assignments alone. An international education provides managers with more knowledge and greater exposure of the dynamics in the international environment [2], [48]. [49] indicate that managers need international perspectives and exposure as early as possible to maximize the quality of their global mindset.

\section{E. Theoretical Gap}

Based on the literature, the identified gaps are to address whether international experience, comprising of international assignment and international education could act as catalysts to the development of a global mindset.

\section{THEORETICAL FRAMEWORK}

\section{A. Hypothesis Development}

Based on the literature review and identified theoretical gap, proposed hypotheses are as follows:

$H_{1:}$ An International assignment significantly contributes towards the development of a global mindset.

$H_{2}$ : An international education significantly contributes towards the development of a global mindset.

Fig. 1 below illustrates the hypothesized relationships.

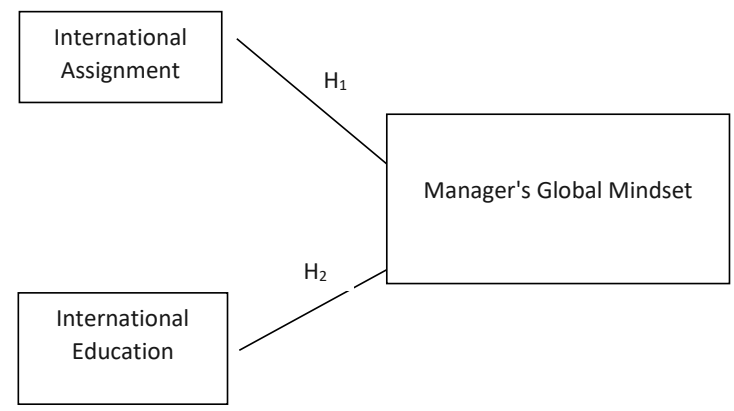

Fig. 1. Theoretical framework of manager's global mindset.

\section{Methodology}

\section{A. Research Design}

This research utilized a quantitative and deductive approach to address the research questions used in formulating the hypothesis in the previous section. The question point in the questionnaire refer to similar previous research namely, research in the global mindset international experience conducted by [15] and [36]. The questionnaire was developed into two different parts comprising general information and specific questions. General information comprises of several participant backgrounds such as age, gender, country of origin, position, international experience, and level of education.

\section{B. Data Analysis Procedures}

This research utilizes Partial Least Square (PLS) software to process and analyses the obtained data. Exploratory factor analysis was conducted to determine the significant latent variable or factors among the international experiences which contribute to the development of global mindset variables. The exploratory factor analysis was selected because this research involves several independent variables, and the purpose of this study was to determine those international experience factors that contribute to the development of a global mindset.

\section{Study Setting}

For the sampling process, one-stage cluster sampling was utilized where five chosen districts were each selected in Singapore and Mexico City. In practice, each district contributed by providing two MNCs which had been selected randomly. In Singapore, the districts from which companies were selected included the Central Business District (Downtown), Marina Bay, Changi Business Park, Sembawang, and Jurong East. In Mexico City, the districts included Santa Fe, Cuauhtémoc, Ecatepec, Reforma, and Toluca.

\section{Research Participants}

This research participants consist of 80 individuals from the senior level, senior executive, board of directors, and CEO of 10 Multinational company across the two cities from various business sectors such as telecommunications, logistics, banking, finance, energy, construction, healthcare, and the pharmaceutical industry. 


\section{RESEARCH FINDINGS}

\section{A. Background of Respondents}

Questionnaire were physically distributed in this research. In total, 95 questionnaires were distributed between $14^{\text {th }}$ January to $28^{\text {th }}$ January 2019. Overall, the questionnaires yielded an $84 \%$ response rate with 80 valid questionnaires obtained. The high response rate could be due to the fact that questionnaires were physically distributed. The following table shows descriptive data including respondents' age, gender, country of origin, job (managerial) position, international experience, and level of education. Fig. 2 summarizes the descriptive data.
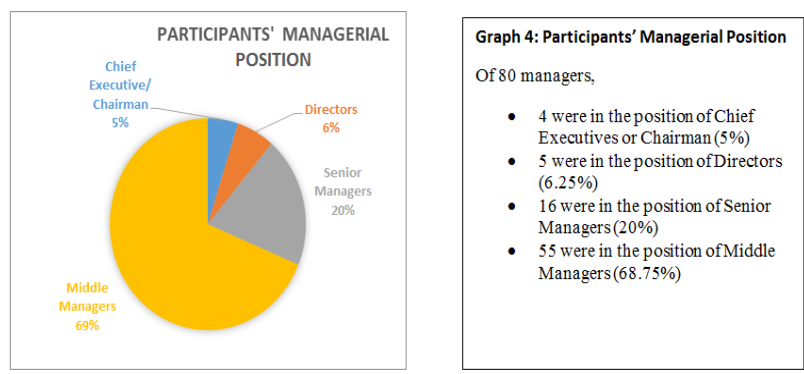

(Source: Authors' analysis)

Fig. 2. Background of respondents

\section{B. Composite Reliability Test}

Composite reliability does not estimate a construct's internal consistency. In contrast to Cronbach's alpha, composite reliability does not assume that all research indicators as a whole are equally reliable, making it more appropriate to utilize in PLS models which usually priorities indicators (dimensions) based on their reliability during the model assessment [50]. [51] asserted that composite reliability values of 0.60 to 0.70 in exploratory research context are acceptable values, whereas values below 0.60 signify inadequate reliability. Indicators that produce value below than 0.40 should be eliminated from the scale results [51], [52]. Additionally, composite reliability was also utilized in examining the internal consistency, whose acceptable number of benchmark should be more than 0.7 to be considered adequate [52].

The test result shows that International Assignment (IA) and International Education (IE) have values of 0.748 and 0.794 , respectively, which are higher than 0.70 , thereby indicating that the variables have acceptable levels of reliability and consistency. This indicates that the data collection process was adequate and could be continued to the next step of analysis. Table I summarizes the results of the Composite Reliability Test discussed.

TABLE I: COMPOSITE RELIABILITY TEST RESULT

\begin{tabular}{|l|c|c|}
\hline \multicolumn{1}{|c|}{ Variables } & $\begin{array}{c}\text { Number of } \\
\text { Indicators }\end{array}$ & $\begin{array}{c}\text { Composite Reliability } \\
\text { Value }\end{array}$ \\
\hline $\begin{array}{l}\text { International } \\
\text { Assignment (IA) }\end{array}$ & 2 & 0.748 \\
\hline $\begin{array}{l}\text { International } \\
\text { Education (IE) }\end{array}$ & 2 & 0.794 \\
\hline
\end{tabular}

(Source: Authors' analysis)

\section{Average Variance Extracted (AVE) Validity Test}

Average variance extracted (AVE) was used as a measure of convergent validity in a latent variable [53]. This condition allows researchers to explain the shared predictive power (IA and IE) over the dependent variable (global mindset). [52] also suggest that adequately convergent latent variables should have measures that contain a value greater than 0.5 AVE. In this research, International Assignment variable (IA) has 0.515 and International Education has 0.659 . Thus, the results indicate that both International Assignment (IA) and International Education (IE) have met the AVE validation expectation level and are adequately convergent in factor analysis. In other words, both variables (constructs) are capable of explaining another variable (construct). Table II summarizes the results of the Average Variance Extracted (AVE) validity test.

TABLE II: VALIDITY TEST RESULT

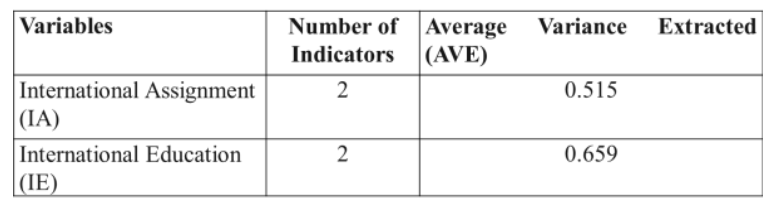

(Source: Authors' analysis)

\section{Correlation Analysis}

The purpose of correlation analysis is to measure the strength of the relationship between variables. Correlation analysis generated varied value from -1 to 1 , whereby the value of the correlation between 0.5 to 1.0 or -0.5 to 0.1 means the correlation relationship is high, while generated value between 0.3 to 0.5 or -0.3 to 0.1 is possess medium correlation, and 0.1 to 0.3 indicates weak correlation relationship between variables [54], [55]. Table III below presents a summary of the correlation analysis.

TABLE III: CORRELATION TEST RESULTS

\begin{tabular}{l|l|r|r|r|r|r|r|}
\hline & \multicolumn{1}{|c|}{ IA1 } & \multicolumn{1}{|c|}{ IA2 } & \multicolumn{1}{c|}{ IE1 } & \multicolumn{1}{c|}{ IE2 } & \multicolumn{1}{c|}{ MGM1 } & \multicolumn{1}{c|}{ MGM2 } \\
\hline IA1 & 1.000 & 0.031 & 0.401 & 0.299 & 0.139 & 0.293 \\
\hline IA2 & 0.031 & 1.000 & 0.090 & 0.251 & -0.012 & 0.199 \\
\hline IE1 & 0.401 & 0.090 & 1.000 & 0.318 & 0.205 & 0.193 \\
\hline IE2 & 0.299 & 0.251 & 0.318 & 1.000 & 0.180 & 0.257 \\
\hline
\end{tabular}

$$
\begin{gathered}
\mathrm{IA}=\text { International Assignment } \\
\mathrm{IE}=\text { International Education } \\
\mathrm{MGM}=\text { = Manager's Global Mindset }
\end{gathered}
$$

\section{E. International Assignment and Global Mindset}

A multivariate correlation test showed a moderately low correlation ( 0.1 to 0.3$)$ between indicators of International Assignment and Global Mindset. This signifies that there is a relationship among the variables, although the correlation value is low. Specifically, overseas job experience (INTA1) produced a 0.139 positive correlation value toward (MGM1) and 0.293 toward (MGM2). In other words, (MGM1) will increase in value concurrently with the increase of (MGM2) and vice versa. The results also indicate that correlation between (INTA1) and (MGM2) have the strongest relationship compared to others.

However, a distinctive result was displayed in the International Assignment (INTA2) correlation outcome. The correlation result of participation in international project 
(INTED2) showed -0.012 toward MGM1 and 0.199 to MGM2, thus produce a negative relationship between the variables. The correlation results suggest MGM1 relationship will decrease if the correspondent variable (MGM2) value's increase (Saunders, 2019).

\section{F. International Education on Global Mindset}

The correlation of overseas training (INTED1) toward MGM1 and MGM2 suggests a positive relationship, whereby the relationship strength that affects the associated variable, produces a 0.205 correlation value between INTED2 and MGM1, and 0.193 between INTED1 and MGM2. For example, an increase in correlation strength between INTED 1 and MGM1 will simultaneously increase the correlation strength between INTED1 and MGM2. Similarly, the result suggests that INTED2 and MGM1 has $0.180 \mathrm{MGM} 1$ and has 0.257 to MGM2, by which produces a positive relationship within variables.

\section{G. P-value Analysis}

The $\mathrm{P}$ value table presents the significance level of International experience variables comprising of International Assignment (IA) and International Education (IE) toward a manager's Global Mindset (MGM). Through the factor analysis method, the results (See Table IV) indicate that International Assignment (IA) has 0.000 significance value, since 0.000 is less than 0.001 it can be contended that International Assignment (IA) is highly significant towards the development of Manager's Global Mindset (MGM). Similarly, the result indicates that International Education (IE) has a 0.003 significance value as 0.0003 is less than 0.001 it can be argued that International Education (IE) is significant toward the development of Manager's Global Mindset (MGM).

Additionally, the result suggests that both IA and IE have produced a 0.025 standard deviation value, while yielding a 0.109 and 0.077 sample mean value respectively. This condition indicates that the distribution of data sample is acceptable, since a higher sample mean $(0.25$ for both IA and IE) than standard deviation (0.109 (IA) and 0.077 (IE) leads to acceptable distribution data [56]. Table IV shows a summary of the $P$-Value Analysis results.

TABLE IV: $P$-VALUE ANALYSIS RESUlT

\begin{tabular}{|l|l|l|l|}
\hline Variable & $\begin{array}{l}\text { Standard } \\
\text { Deviatio } \\
\mathbf{n}\end{array}$ & $\begin{array}{l}\text { Sample } \\
\text { Mean }\end{array}$ & $\begin{array}{l}\boldsymbol{P} \text { - } \\
\text { values }\end{array}$ \\
\hline $\begin{array}{l}\text { International Assignment (IA) } \rightarrow \\
\text { Manager's Global Mindset (MGM) }\end{array}$ & 0.025 & 0.109 & 0.000 \\
\hline $\begin{array}{l}\text { International Education (IE) } \rightarrow \text { Manager's } \\
\text { Global Mindset (MGM) }\end{array}$ & 0.025 & 0.077 & 0.003 \\
\hline
\end{tabular}

(Source: Authors' analysis)

\section{H. Path Coefficient Analysis}

Path coefficient analysis displays which indicator contributes to the formation of a manager's global mindset variable. Based on the result figure (See exhibit 3), International Assignment (IA) possess 0.113 value which formed by two indicators comprise of (INTA1) and (INTA2) that have value of 0.811 and 0.813 , respectively. The result indicates that both INTA1 and INTA2 describe the International Assignment variable, since both variables have more than 0.5 coefficient value [57]. In comparison within the construct indicators, it can be argued that (INTA2) has the largest contribution within the international assignment context. This condition suggests that overseas job assignment is important for manager global mindset development and mostly represents the International Assignment variable. The Path Coefficient Analysis is summarized in Fig. 3.

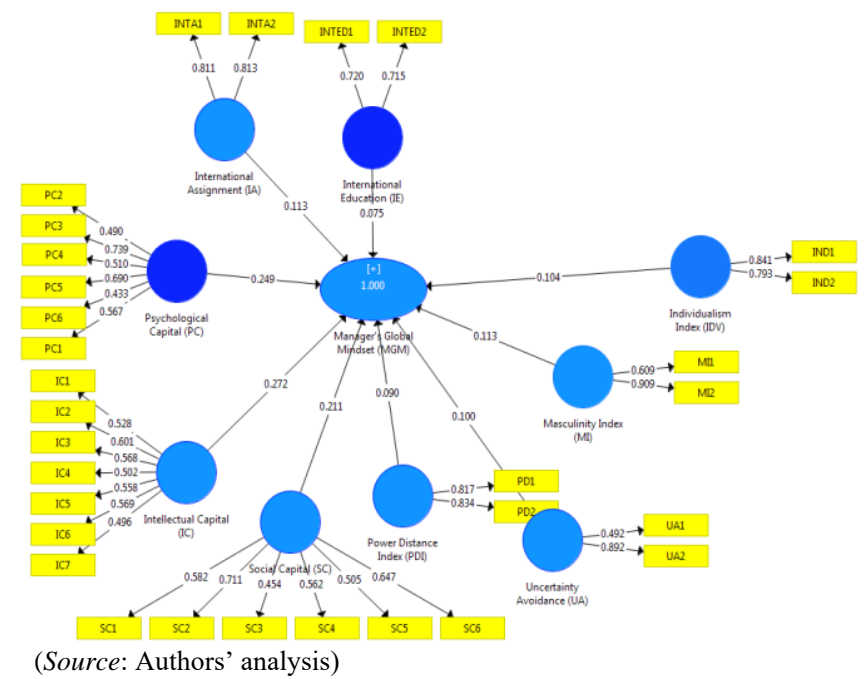

Fig. 3. Path coefficients analysis diagrams.

Similarly, for International Education (IE) there are two indicators that construct the variables which (INTED1) and (INTED2) have 0.720 and 0.715 respectively. The results suggest that both variables illustrate International Education (IE), since both variables have more than 0.5 coefficient values. Furthermore, the research results also suggest that INTED1 is the most representative variable in International Education (IE). Hence, it can be argued that INTED1 questionnaire statement "Overseas training and seminar influence manager global mindset development" is a statement that represents International Education the most.

\section{DISCUSSION}

\section{A. International Assignment on Managers' Global Mindset}

Based on previous literature, our research built a model that focused on international experience as a predictor of managerial global mindset. Our research has also found that the international assignment variable is significant to a manager's global mindset orientation at the 0.001 trust level. Moreover, it was found that each latent variable that constructs the International Assignment variable has successfully represented the variable (See Exhibit 3). Therefore, it could be argued that both overseas job experience and participation in international projects should not be neglected in shaping this variable. Global mindset was triggered by the fact that managers tend to have strong interest in conducting business abroad, accept different viewpoints, ideas and desire to grasp any advantages of international opportunities [1], [58]. In this sense, both international assignment and international project participation could be the foundation or springboard to 
unlock the potential of a manager's global mindset. Evidence by [1] and [59] support this view. They found that the willingness to explore global business opportunities such as international assignments and project participation is derived from the global mindset orientation. Moreover, [60] found that a manager's international activity and experiences tend to be associated with open-minded characteristics and perceptions of diverse cultures and realities in which global mindset philosophies are rooted. Additionally, international assignment and project participation are related to the development of commercial expertise together with management across cultures and the ability to speak various languages [3]. Empirical studies from several researchers found that international assignment and international project participation have become appraisal methods of managers' global mindset development and an important element of a manager's background [3], [17], [36], [61].

\section{B. International Education on Manager's Global Mindset}

Research findings have implied that international education has significantly contributed to managers' global mindset development at 0.001 confidence level. In particular the path coefficient analysis has found that overseas training and seminars (INTED1) and overseas education (INTED2) are capable of representing these variables. This condition suggests that both construct variables should not be excluded in shaping the International (IE) variable. International training and seminar (INTED1), as well as overseas education (INTED2) are associated with the development of a manager's knowledge. [62] argued that knowledge tends to be regarded as an asset. Knowledge accumulation through training and education will assist managers learning orientation with the aim to increase their international competences, vision and awareness regarding the existing opportunities in the international level [47], [63] Moreover, overseas education and training overseas directly increase manager's exposure toward uncertain and new condition [6], [46], [64]. This exposure could be an early development in the global mindset orientation since it would assist a manager to engage and thrive in an international business environment [6], [46].

However, the utilization of factor analysis allows us to justify which variable is the most important among the others. Based from the research finding, overseas training and seminar (INTA1) produces a slightly higher value than overseas education (INTA2). This result suggest that managers perceive overseas training and seminars to have higher contribution in stimulating global mindset compared to overseas education. Training and seminars tend to elaborate on specific practical knowledge, while education tends to emphasize theoretical knowledge accumulation [65], [66]. In this sense, practical knowledge will assist a manager to acquire specific techniques and knowledge more closely related to the development of a global mindset.

Moreover, practical knowledge often leads to deeper understanding through application and personal experience in the real world, resulting in the stimulation of a global mindset orientation [28], [46], [67]. Moreover, prior empirical research also failed to find a relationship between overseas education and global mindset [67]. Therefore, this indicates that overseas training and seminar has more contribution toward the development of global mindset.

\section{CONCLUSION}

Global mindset has become an important aspect for managers to compete in the interconnected and interdependence business marketplace. Such characteristic will augment manager to influence and manage others even though several differences such as culture, political, and other contextual factor would affect their judgements and actions. To stimulate this mindset, it is suggested that managers should participate in international experience such as international assignment and international education. This research utilized smart PLS and factor analysis model to identify the latent variable within the international experience variable that contribute to the development of global mindset.

This research found that international assignment and international education are significantly contributes toward the development of global mindset orientation. Furthermore, the result shown that international training and seminar construct variable possess higher value compare to international education. Additionally, the research also suggests that International assignment possess higher magnitude value compare to international education.

\section{IMPLICATIONS}

\section{A. Theoretical Implications}

This research is contributed to the development of the global mindset context since discussion of the latent variable that associate within the global mindset development are novel and considered as new. Moreover, the variable justification within the international educational determinate specifically which variable that contributed to the development of global mindset orientation. Therefore, future research could attempt to find evidence and generalization of the observed variable in a more efficient way.

\section{B. Practical Implications}

The results of this research conclude that international assignment possesses better benefits towards the development of a global mindset orientation. Such results suggest that organizations should emphasize managerial development by expatriation or overseas assignments and involvement in international projects. Moreover, human resource management that is willing to spend more capital on managerial development through education should focus on training and seminars rather than overseas education since they tend to be less costly and less time consuming and more practical towards a manager's progression, particularly their global mindset orientation.

\section{LIMITATIONS}

From a methodology perspective, one-stage cluster sampling was carried due to financial and time constraints. In this sense, several disadvantages arise. Cluster 
determination that used in this method does not represent the general population sample and thus would affect the researchers' ability to produce generalized results. Similarly, this research focuses on Singapore and the conclusion and result of this research may not be applicable outside Singapore. The research also limited on certain indicator for shaping the variables. In other words, the variable development in this research might neglect some indicators that potentially contribute to the reliability and validity of the variables.

\section{CONFLICT OF INTEREST}

The authors declare no conflict of interest.

\section{AUTHOR CONTRIBUTIONS}

The first and third authors (Wollenberg and Rizal) reviewed the literature and developed the theoretical constructs and research design along with data collection in Singapore. The second author (Cabrera-Lazarini) also tailored the theoretical models to a comparative context between the two countries (Singapore and Mexico). The first and second authors (Wollenberg and Cabrera-Lazarini) collected data in Mexico City and jointly conducted analysis on the data collected in Mexico City. All authors were involved in writing the final version of the article, which was edited by the first author (Wollenberg). All authors had approved the final version.

\section{ACKNOWLEDGMENT}

The authors wish to thank Khalifa University, Tecnológico de Monterrey, and Curtin University, as well the research participants for their support in conducting this study.

\section{REFERENCES}

[1] A. K. Gupta and V. Govindarajan, "Cultivating a global mindset," Academy of Management Perspectives, vol. 16, no. 1, pp. 116-126, 2002.

[2] N. Nummela, S. Saarenketo, and K. Puumalainen, "A global mindset A prerequisite for successful internationalization?" Canadian Journal of Administrative Sciences/Revue Canadienne des Sciences de l'Administration, vol. 21, no. 1, pp. 51-64, 2004.

[3] C. Bouquet, A. Morrison, and J. Birkinshaw, Determinants and Performance Implications of a Global Mindset: An Attention-Based Perspective, 2005, Bibliotheque et Archives Canada.

[4] M. Javidan and J. L. Walker, "A whole new global mindset for leadership," People and Strategy, vol. 35, no. 2, pp. 36-41, 2012.

[5] J. Cohen, P. Cohen, S. G. West, and L. S. Aiken, Applied Multiple Regression/Correlation Analysis for the Behavioural Sciences, 2013 Routledge.

[6] P. D. Harveston, B. L. Kedia, and P. S. Davis, "Internationalization of born global and gradually globalizing firms: The impact of the manager," Journal of Competitiveness Research, vol. 8, no. 1, pp. 92$99,2000$.

[7] B. S. R. Harzing and A. Will, "International assignment," in International Human Resource Management, 3rd ed. A. W. K. Harzing and A. Pinnington, Eds.

[8] M. A. Carpenter, G. W. Sanders, and H. B. Gregersen, "International assignment experience at the top can make a bottom-line difference," Human Resource Management, vol. 39, no. 2-3, pp. 277-285, 2000.

[9] J. S. Osland and A. Bird, "Process models of global leadership development," in Global Leadership: Research, Practice, and Development, M. E. Mendenhall, J. S. Osland, A. Bird, G. R. Oddou, M. L. Maznevski, M. J. Stevens, and G. K. Stahl, Eds. New York: Abingdon, 2013, pp. 97-112.

[10] S. H. Rhinesmith, "Open the door to a global mindset," Training and Development, vol. 49, no. 1, pp. 34-44, 1995.
[11] P. C. Earley, C. Murnieks, and E. Mosakowski, "Cultural intelligence and the global mindset," Advances in International Management, vol. 19, no. 1, pp. 75-103, 2007.

[12] R. Aggarwal, "Developing a global mindset. Integrating demographics, sustainability, technology, and globalization," Journal of Teaching in International Business, vol. 22, no. 1, pp. 51-69, 2011.

[13] T. P. Murtha, S. N. Lenway, and R. P. Bagozzi, "Global mindsets and cognitive shifts in a complex multinational corporation," Strategic Management Journal, vol. 19, no. 2, pp. 97-114, 1998.

[14] B. L. Kedia and A. Mukherji, "Global managers: Developing a mindset for global competitiveness," Journal of World Business, vol. 34 , no. 3, pp. 230-251, 1999.

[15] J. S. Osland, A. Bird, and M. E. Mendenhall, "11 Developing global leadership capabilities and global mindset: A review," in Handbook of Research in International Human Resource Management, G. K. Stahl and I. Bjorkmann, Eds. Cheltenham: Edward Elgar, 2006, pp. $197-$ 222.

[16] M. L. Maznevski and H. W. Lane, "Shaping the global mindset: Designing educational experiences for effective global thinking and action," in Teaching and Experiencing Cross Cultural Management: Lessons from Master Teachers, New York: Routledge, 2004, pp. 171184.

[17] R. L. Engle and K. A. Crowne, "The impact of international experience on cultural intelligence: An application of contact theory in a structured short-term programme," Human Resource Development International, vol. 17, no. 1, pp. 30-46, 2014.

[18] K. A. Crowne, "What leads to cultural intelligence?" Business Horizons, vol. 51, no. 5, pp. 391-399, 2008

[19] L. Y. Lee and B. M. Sucoco, "The effects of cultural intelligence on expatriate performance: The moderating effects of international experience," The International Journal of Human Resource Human Resource Management, vol. 21, no. 7, pp. 963-981, 2010.

[20] P. C. Earley and R. S. Peterson, "The elusive cultural chameleon Cultural intelligence as a new approach to intercultural training for the global manager," Academy of Management Learning \& Education, vol. 3, no. 1, pp. 100-115, 2004.

[21] A. Yan, G. Zhu, and D. T. Hall, "International assignments for career building: A model of agency relationships and psychological contracts," Academy of Management Review, vol. 27, no. 3, pp. 373391, 2002

[22] R. Clapp-Smith and T. Wernsing, "The transformational triggers of international experiences," Journal of Management Development, vol. 33, no. 7, pp. 662-679, 2014.

[23] S. Ang and A. C. Inkpen, "Cultural intelligence and offshore outsourcing success. A framework of firm-level intercultural capability," Decision Sciences, vol. 39, no. 3, pp. 337-358, 2008.

[24] G. M. Spreitzer, M. W. McCall, and J. D. Mahoney, "Early identification of international executive potential," Journal of Applied Psychology, vol. 82, no. 1, pp. 6-29, 1997.

[25] M. J. Morley, J. L. Cerdin, A. Bird, M. Mendenhall, M. J. Stevens, and G. Oddou, "Defining the content domain of intercultural competence for global leaders," Journal of Managerial Psychology, vol. 25 , no. 8 , pp. $810-828,2010$

[26] A. Bird, J. S. Osland, H. W. Lane, M. L. Maznevski, M. E. Mendenhall, and J. McNett, "Global competencies: An introduction," in The Blackwell Handbook of Global Management: A Guide to Managing Complexity, 2004, pp. 57-80.

[27] M. E. Mendenhall and G. K. Stahl, "Expatriate training and development: Where do we go from here?" Human Resource Management, vol. 39, no. 2-3, pp. 251-265, 2000.

[28] A. Arora, J. Anupam, A. G. Kefalas, and T. Perenich, "An exploratory analysis of global managerial mindsets: A case of the US textile and apparel industry," Journal of International Management, vol. 10, no. 3, pp. 393-411, 2004.

[29] Z. Aycan, "Expatriation: A critical step toward developing global leaders. Developing global business leaders," in Developing Global Business Leaders: Policies, Processes, and Innovations, M. E. Mendenhall, T. M. Kuehlmann, and G. K. Stahl, Eds. 2001, pp. 119 135.

[30] J. S. Black, A. J. Morrison, and H. B. Gregersen, Global Explorers: The Next Generation of Leaders, 1999, Psychology Press.

[31] J. Selmer, I. Torbiorn, and C. T. Leon, "Sequential cross-cultura training for expatriate business managers: Pre-departure and postarrival," International Journal of Human Resource Management, vol 9, no. 5, pp. 831-840, 1998.

[32] D. C. Thomas, E. Elron, G. K. Stahl, B. Z. Ekelund, E. C. Ravlin, J. L. Cerdin, S. Poelmans, R. Brislin, A. Pekerti, and Z. Aycan, "Cultural intelligence domain and assessment," International Journal of CrossCultural Management, vol. 8, no. 2, pp. 123-143, 2008. 
[33] H. B. Gregersen, A. J. Morrison, and J. S. Black, "Developing leaders for the global frontier," Sloan Management Review, vol. 40, no. 1, pp. 21-33, 1998.

[34] G. P. Hollenbeck and M. W. McCall, "Competence, not competencies: Making global executive development work," Advances in Global Leadership, vol. 3, no. 1, pp. 101-119, 2003.

[35] G. K. Stahl, E. L. Miller, and R. L. Tung, "Toward the boundaryless career: A closer look at the expatriate career concept and the perceived implications of an expatriate assignment," Journal of World Business, vol. 37, no. 3, pp. 216-227, 2002.

[36] A. S. Lovvorn and J. S. Chen, "Developing a global mindset: The relationship between an international assignment and cultura intelligence," International Journal of Business and Social Science, vol. 2, no. 9, pp. 275-283, 2011

[37] C. M. Daily, S. T. Certo, and D. R. Dalton, "International experience in the executive suite: The path to prosperity?" Strategic Management Journa, vol. 21, no. 4, pp. 515-523, 2000.

[38] G. K. Stahl and I. Bjorkman, Handbook of Research in International Human Resource Management, Edward Elgar Publishing, 2006.

[39] R. C. Kjar, "Global mindset: Characteristics and contributing factors," Doctoral Dissertation, 2007.

[40] L. Dragoni, I. S. Oh, P. E. Tesluk, O. A. Moore, P. Vankatwyk, and J. Hazucha, "Developing leaders' strategic thinking through global work experience: The moderating role of cultural distance," Journal of Applied Psychology, vol. 99, no. 5, pp. 867-882, 2014.

[41] L. Segil, M. Goldsmith, and J. A. Belasco, Partnering: The New Face of Leadership, AMACOM, 2003.

[42] S. E. Kaplan, J. A. Samuels, and J. Cohen, "An examination of the effect of CEO social ties and CEO reputation on nonprofessiona investors' say-on-pay judgments," Journal of Business Ethics, pp. 115,2013

[43] G. R. Oddou and M. E. Mendenhall, "Succession planning for the $21^{\text {st }}$ century: How well are we grooming our future business leaders?" Business Horizons, vol. 34, no. 1, pp. 26-34, 1991.

[44] J. S. P. Story, J. E. Barbuto, F. Luthans, and J. A. Bovaird, "Meeting the challenges of effective international HRM. analysis of the antecedents of global mindset," Human Resource Management, vol. 53, no. 1, pp. 131-155, 2014.

[45] P. M. Caligiuri and L. Dragoni, "Global leadership development," The Routledge Companion to International Human Resource Management, pp. 226-251, 2014.

[46] J. Weerawardena, G. S. Mort, P. W. Liesch, and G. Knight, "Conceptualizing accelerated internationalization in the born global firm: A dynamic capabilities perspective," Journal of World Business, vol. 42, no. 3, pp. 294-306, 2007

[47] J. M. Bloodgood, H. J. Sapienza, and J. G. Almeida, "The internationalization of new high-potential US ventures: Antecedents and outcomes," Entrepreneurship Theory and Practice, vol. 20, pp. 61-76, 1996.

[48] S. Anantharam, D. Pick, and T. Issa, "Antecedents of a global mindset A mixed method analysis of Indian, Chinese, and Japanese managers,' Contemporary Management Research, vol. 8, no. 4, pp. 305-330, 2012.

[49] N. M. Pless, T. Maak, and G. K. Stahl, "Developing responsible global leaders through international service-learning programs: The Ulysses experience," Academy of Management Learning \& Education, vol. 10, no. 2, pp. 237-260, 2011

[50] D. R. Bacon, P. L. Sauer, and M. Young, "Composite reliability in structural equations modeling," Educational and Psychological Measurement, vol. 55, no. 3, pp. 394-406, 1995.

[51] J. C. Nunnally and I. H. Bernstein, "The assessment of reliability," Psychometric Theory, vol. 3, no. 2, pp. 248-292, 1994.

[52] C. L. Fornell and D. F. Larcker, "Evaluating structural equation models with unobservable with unobservable variables and measurement error," Journal of Marketing Research, vol. 18, no. 1, pp. 39-50, 1981.

[53] J. F. Hair, C. M. Ringle, and M. Sarstedt, "PLS-SEM: Indeed a silver bullet," Journal of Marketing Theory and Practice, vol. 19, no. 2, pp. 139-152, 2011

[54] G. Norman, "Likert scales, levels of measurement and the laws of statistics," Advances in Health Sciences Education, vol. 15, no. 5, pp. $625-632,2010$
[55] J. Benesty, J. Chen, Y. Huang, I. Cohen, "Pearson correlation coefficient," in Noise Reduction and Speed Processing, Springer, 2009, pp. 37-40

[56] J. M. Bland and D. G. Altman, "Statistics notes: Measurement error," $B M J$, vol. 313 , no. 106, p. 744,1996

[57] J. Henseler, C. M. Ringle, and R. R. Sinkovics, "The use of partial least squares path modelling in international marketing," Advances in International Marketing, vol. 20, no. 1, pp. 277-320, 2009.

[58] V. Pucik and T. Saba, "Selecting and developing the global versus the expatriate manager: A review of the state-of-the-art," Human Resource Planning, vol. 21, no. 4, pp. 40-54, 1998

[59] M. Harvey and M. M. Novicevic, "Selecting expatriates for increasingly complex global assignments," Career Development International, vol. 6, no. 2, pp. 69-87, 2001

[60] S. Beechler and M. Javidan, "Leading with a global mindset," in The Global Mindset, M. Javidan, R. M. Steers, and M. A. Witt, Eds. 2007 pp. 131-169.

[61] P. S. Adler and S. W. Kwon, "Social capital: Prospects for a new concept," Academy of Management Review, vol. 27, no. 1, pp. 17-40, 2002.

[62] J. Naik, G. Iyengar, and R. Lee, "Knowledge management process framework," Knowledge Management: Principles and Applications pp. 83-100, 2003.

[63] E. Autio, H. J. Sapienza, and J. G. Almeida, "Effects of age at entry, knowledge intensity, and imitability on international growth," Academy of Management Journal, vol. 43, no. 5, pp. 909-924, 2000.

[64] L. W. Busenitz and J. B. Barney, "Differences between entrepreneurs and managers in large organizations: Biases and heuristics in strategic decision-making," Journal of Business Venturing, vol. 12, no. 1, pp. 9-30, 1997.

[65] D. DeClercq, H. J. Sapienza, R. I. Yavuz, and L. Zhou, "Learning and knowledge in early internationalization research: Pas accomplishments and future directions," Journal of Business Venturing, vol. 27, no. 1, pp. 143-165, 2012.

[66] S. L. Cohen, "Effective global leadership requires a global mindset," Industrial and Commercial Training, vol. 42, no. 1, pp. 3-10, 2010.

[67] E. Rausch, D. Elmuti, W. Minnis, and M. Abebe, "Does education have a role in developing leadership skills?" Management Decision vol. 43, no. 7, pp. 1018-1031, 2005.

Copyright (C) 2020 by the authors. This is an open access article distributed under the Creative Commons Attribution License which permits unrestricted use, distribution, and reproduction in any medium, provided the original work is properly cited (CC BY 4.0).

Alexander Wollenberg is a professor at Khalifa University, UAE, and obtained his PhD from National University of Singapore in 2011 specializing in innovation-based productivity growth of high-tech companies in emerging economies and a master of arts in international relations from Waseda University in Tokyo, Japan, focusing on technology transfer of Japanese companies in East Asia. In addition to being a member of the Editorial Advisory Board of IGI Global Publishing and the technical committee of International Economics Development and Research Center, Alexander has held various appointments in academia and consultancy in Singapore, Indonesia, Colombia, México, and the West Indies. He is also co-founder of a Singaporean start-up focused on smart-home solutions. His research interests include regional economic integration and effects on value chains, as well as the new economy in emerging countries.

Juan José Cabrera-Lazarini is the dean of the faculty and professor of International Business at Tecnológico de Monterrey in Mexico. His line of research is related to value chain strategy. Dr. Cabrera completed his $\mathrm{PhD}$ in management at Universidad Autónoma de Querétaro and he has been a visiting professor in several university programs in Canada, Finland, Germany, Taiwan, and Colombia. Previous to that, Dr. Cabrera developed a 25-year career in the industry in Manufacturing and Logistics Operations in World Class Companies in several countries including USA, México and Costa Rica

Mohammed Reinaldo Rizal is research fellow at Curtin University, Singapore Campus. 